\title{
Structural family therapy untuk memperbaiki interaksi dalam keluarga
}

$\Phi$ PROCEDIA Studi Kasus dan Intervensi Psikologi p-ISSN 2302-1462; e-ISSN 2722-7669 ejournal.umm.ac.id/index.php/procedia 2021, Vol 9(3):113-118

DOI:10.22219/procedia.v9i3.16454

(C) The Author(s) 2021

()(i) 4.0 International license

\author{
Herliana Rahmi Saputri ${ }^{1}$
}

\begin{abstract}
Problems in the family is the result of a reaction to the social interaction between family members.Bad communication and obscurity of interaction between family members leads to misunderstandings in family relationships. Structural Family Therapy used to improve the pattern of communication in the family. The subject consists of three members of the family. The data were obtained using interview and observation. The intervention was carried out in five sessions. The results of the intervention were each family member has a good pattern of communication, reduced misunderstandings, clear regulations and role in the interaction between them.
\end{abstract}

\section{Keywords}

Family interaction, patterns of communication, structural family therapy, regulation, members family role

\section{Pendahuluan}

Keluarga adalah dua atau lebih dari dua individu yang tergabung karena hubungan darah, hubungan pernikahan atau pengangkatan dan mereka hidup dalam satu rumah tangga, berinteraksi satu sama lain dan didalam perannya masing-masing menciptakan serta mempertahankan kebudayaan (Friedman, 2010). Fungsi keluarga adalah ukuran dari bagaimana sebuah keluarga beroperasi sebagai unit dan bagaimana anggota keluarga berinteraksi dan berperan satu sama lain. Hal ini mencerminkan gaya pengasuhan, konflik keluarga, dan kualitas hubungan keluarga (Cooper et al., 2007). Interaksi antar anggota keluarga juga diarahkan untuk pembentukan nilai-nilai kehidupan, terutama oleh orang tua kepada anak-anak. Beberapa nilai kehidupan penting yang perlu dikembangkan dalam diri anak adalah kejujuran, kepedulian, keadilan dan integritas. Namun tidak semua keluarga dapat menjalankan fungsinya masing-masing sehingga terjadi masalah.

Minuchin (1974) mengemukakan jika seseorang individu bermasalah, masalah bukan terletak dalam diri individu, melainkan dalam interaksi individu dengan lingkungan sosial keluarganya. Minuchin juga mengatakan bahwa setiap keluarga memiliki struktur yang mana ini adalah tuntutan dan fungsi yang dijalankan oleh setiap anggota keluarga dalam interaksi. Struktur ini nampak samarsamar, bahkan tidak terlihat ketika keluarga dalam keadaan seimbang. Struktur menjadi nyata bila timbul gejolak dan masalah dalam keluarga. Dalam keluarga disfungsi akan tergambar jelas bahwa boundaries nampak kaku atau kabur, terjadi koalisi, terjadi enmeshed, disengaged, atau triangulasi.
Artinya, bila seorang anggota keluarga mempunyai suatu masalah, maka kondisi ini merupakan reaksi terhadap perilaku anggota keluarga lain, atau sebaliknya. Semua masalah yang terjadi didalam keluarga merupakan hasil interaksi sosial dalam suatu sistem. Hal inilah yang terjadi pada subjek. Ibu kakak dan adik mengalami suatu sistem yang kurang baik dalam keluarga terutama komunikasi dan peran, sehingga membuat anggota keluarga bermasalah khususnya adik (sering membolos dan berbohong).

Oleh sebab itu, dijalankannya structural family therapy ini bertujuan untuk mengubah struktur dalam keluarganya dengan cara menyusun kembali (restrukturisasi) kesatuan dan menyembuhkan perpecahan yang terjadi dalam suatu keluarga. Diharapkan keluarga dapat menantang persepsi untuk melihat realitas, mempertimbangkan alternatif khususnya komunikasi dan peran masing-masing anggota keluarga sehingga keluarga dapat mengembangkan pola hubungan yang baru dan struktur yang mendapatkan self reinforcing (Minuchin, 1982).

\section{Metode Asesmen}

Prosedur asesmen psikologi bertujuan untuk mengumpulkan data subjek dengan metode observasi dan

\footnotetext{
${ }^{1}$ UPT Perlindungan Perempuan dan Anak (PPA), Kabupaten Berau, Kalimantan Timur

Korespondensi:

Herliana Rahmi Saputri, UPT Perlindungan Perempuan dan Anak (PPA), Kabupaten Berau, Kalimantan Timur

Email: saputrirahmii@gmail.com
} 
wawancara. Observasi dilakukan pada saat membangun raport, wawancara dan selama proses terapi berlangsung. Tujuan observasi adalah untuk melihat dan memahami makna dari suatu perilaku. Wawancara dilakukan dengan setiap anggota keluarga untuk mendapatkan informasi yang lebih faktual dan lebih mendalam. Melalui wawancara dan observasi, permasalahan dapat ditangkap dengan baik sehingga tidak diperlukan alat tes lainnya untuk menggali permsalahan.

\section{Presentasi Kasus}

Berdasarkan hasil asesmen diketahui, anggota keluarga terdiri dari Ibu (P/50 tahun), Kakak (L/24 tahun), dan Adik (L/17 tahun). Adik adalah anak bungsu dari 4 bersaudara, memiliki hobi bermain game online, mengedit video dan menjelajahi alam. Adik dan kakak terpaut usia cukup jauh. Kakak pertama (Laki-laki) berumur 30 tahun, kakak kedua (perempuan) 27 tahun, kakak ketiga (laki-laki) 24 tahun. Ayah bekerja sebagai penjual bunga di Nigeria sejak 8 tahun yang lalu. Keluarga sedikit kesulitan berhubungan dengan ayah karena kesibukan ayah dan perbedaan waktu. Ayah tidak menentu untuk pulang ke Indonesia, biasanya ketika lebaran atau memiliki biaya yang cukup untuk transportasi. Ayah memilih mempertahankan pekerjaannya di Nigeria karena gajinya dianggap lebih dari cukup untuk membiayai keluarga. Ayah bekerja di Nigeria atas tawaran teman yang juga bekerja disana sebagai koki. Ibu bekerja sebagai pembantu rumah tangga panggilan. Kakak pertama telah berkeluarga dan menetap di Surabaya, bekerja sebagai karyawan di perusahaan asuransi. Kakak kedua juga telah menikah dan tinggal bersama suaminya di Malang. Kakak ketiga seorang mahasiswa semester akhir di salah satu universitas swasta di Malang. Adik, ibu dan kakak ketiga tinggal bersama di Batu.

Keluarga diorganisasikan dengan ayah sebagai figur yang memegang kendali dan ibu adalah bawahan/ wakilnya. Anak-anak diwajibkan untuk menghormati dan mematuhi tokoh-tokoh otoritatif ini (Connell, 2010). Hilangnya peran ayah dalam keluarga membuat subjek harus mengatur kembali peran yang hilang dan aturanaturan yang jelas didalamnya. Jika peran tidak diperjelas, maka konflik internal keluarga akan rentan terjadi karena timpang tindih peran seperti yang terjadi pada kasus ini.

Semasa kecil adik cukup dekat dengan kakak ketiga karena rentang umur yang paling mendekati. Namun setelah kakak beranjak remaja (SMA) hubungan mereka mulai merenggang. Kakak lebih senang menghabiskan waktu di luar rumah bersama teman-temannya. Mulai sering menyuruh dan memarahinya, jarang meluangkan waktu dan acuh terhadap adik. Semenjak itu adik tidak lagi merasa dekat dengan kakak. Adik merasa bahwa kakak sering berlaku egois terhadapnya, sering memperlakukannya semena-mena seperti giliran memakai motor atau laptop. Kakak sering mengingkari perjanjian yang telah di buat dan sering menunda-nunda kesepakatan.
Ketika berbicara kakak jarang memberinya kesempatan untuk berpendapat dan cenderung hanya ingin didengarkan tanpa mau mendengarkan orang lain. Kakak juga mengatur adik dalam menentukan sesuatu seperti memilih sekolah. Awalnya adik ingin bersekolah di SMA B, namun kakak mengatakan SMA tersebut tidak bagus dan lebih baik di SMA A. Akhirnya adik hanya bisa menuruti kemauan kakak. Ibu pun jarang membela keinginan adik, ibu lebih sering mendengarkan saran kakak. Perlakuan kakak yang paling kasar adalah ketika kakak menamparnya karena membolos dan membuat ibu malu karena dipanggil pihak sekolah. Adik merasa tidak seharusnya kakak berbuat seperti itu.

Kedua kakak yang lain juga sering mengatur adik, namun karena telah berpisah rumah, perilaku tersebut berkurang dengan sendirinya. Adik saat ini keberatan dengan perilaku kakak yang merasa berhak mengatur semena-mena. Hal ini terjadi karena batasan belum jelas. Ketika batasan didefinisikan dengan jelas, masalah keluarga akan berkurang. Namun, jika ada masalah, keluarga tidak berhasil dalam menciptakan solusi yang sehat ketika menggunakan teknik yang berulang dan tidak efektif seperti berteriak, dan bertengkar; ini akan menciptakan konflik dalam keluarga (Cook, 2007).

Adik juga merasa ibunya kurang meluangkan waktu untuknya karena sibuk bekerja sebagai pembantu rumah tangga paruh waktu dan ketika berada di rumah sibuk menonton televisi. Ibu sering memarahi adik karena menghabiskan banyak uang dan waktu di warnet serta jarang keluar kamar ketika berada di rumah. Adik saat ini memiliki kekasih yang juga teman satu sekolahnya namun tidak berani jujur meskipun sebenarnya ia sangat ingin mengatakan hal itu pada ibunya. Adik mengatakan bahwa ibunya melarangnya berpacaran dan menyuruhnya fokus belajar. Adik mengatakan lebih nyaman berada di warnet daripada di rumah karena memiliki banyak teman dan dapat melampiaskan perasaannya ketika bermain game online. Adik merasa kesepian karena kakaknya lebih sering berada di Malang dan ibu bekerja.

Adik mengatakan sering berbohong kepada ibunya karena takut dimarahi. Menurutnya, berbohong dan jujur sama-sama akan mendapat hukuman, sehingga ia lebih memilih untuk berbohong. Adik mengatakan bahwa jika ibunya bersedia menjadi lebih demokratis dan pengertian, ia bersedia menghilangkan kebiasaan berbohongnya. Bahkan ia mengatakan akan lebih betah di rumah jika ibunya lebih banyak menyediakan waktu untuknya, bukan hanya marah kepadanya. Untuk berfungsi dengan baik, batas-batas harus jelas dan tidak terlalu kaku, komunikasi yang baik juga diperlukan agar befungsi maksimal (Minuchin, 1974). Hal ini adalah hal yang kurang diperhatikan subjek dalam permasalahan keluarganya sehingga komunikasi yang buruk dapat menyebabkan konflik.

Ketika masuk SMA, adik semakin kecanduan bermain game online bahkan pernah sampai tidur di warung internet karena takut pulang ke rumah. Dalam lingkungan 
sosial, adik tidak memiliki banyak teman bahkan ia sering menjadi korban perundungan di kelas. Adik sebenarnya sudah pernah melawan tetapi justru ia yang disalahkan oleh gurunya. Guru matematika pun menjadi salah satu orang yang merundung adik di kelas. Adik merasa malu ketika diremehkan oleh gurunya saat salah mengerjakan soal di depan kelas. Adik pernah mengadukan hal tersbut ke pihak BK namun tidak ada tindak lanjut yang serius.

Adik merasa sangat tidak nyaman berada di kelas sehingga akhirnya memilih untuk membolos setiap guru tersebut masuk, hingga saat ini perilaku membolos adik semakin parah. Adik sudah membolos sekolah lebih dari satu minggu, ia juga sering berbohong dengan ibunya. Adik biasanya pamit untuk sekolah dari rumah padahal ia pergi ke warnet. Adik ingin pindah ke sekolah yang dulu ia inginkan sejak awal. Adik pernah memberanikan diri jujur dengan ibunya akan hal itu, namun ibunya tidak ingin adik jika pindah ke sekolah lain karna sekolahnya saat ini adalah sekolah favorit, kakaknya pun tidak menginginkan jika ia pindah.

Hal ini berhubungan dengan pernyataan (Vetere, 2001). yang mengatakan bahwa keluarga dipandang sebagai sistem psikososial, tertanam dalam sistem sosial yang lebih luas, yang berfungsi melalui pola transaksional: transaksi ini ditetapkan pola bagaimana, kapan dan kepada siapa berhubungan, dan mereka mendukung sistemSehingga jika dalam psikososial keluarga anggota keluarga tidak dapat menyesuaikan diri dengan baik, maka bisa jadi anggota keluarga tersebut kesulitan beradaptasi di dunia sosial yang lebih luas dan menyebabkan konflik.

Ibu tidak menyukai perilaku adik yang tidak ingat waktu ketika bermain game. Ibu mengatakan bahwa ia bingung dengan perilaku adik yang sering berbohong, meskipun sudah terbukti tetapi adik tetap mengelak. Seperti saat tidak pulang dan menginap di warnet, ibu mendapat laporan bahwa adik berada di warnet dan mengirimkan foto motor adik yang terparkir di warnet sebagai bukti. Keesokan harinya adik tidak mengaku dan mengatakan menginap di tempat teman untuk mengerjakan tugas kelompok. Padahal ibu sudah menunjukkan bukti foto tersebut namun ia tetap bersikeras bahwa itu bukan dirinya. Ibu mengeluhkan tentang perilaku adik yang tidak pernah pamit jika ingin keluar rumah (kecuali sekolah). Padahal ibu telah mengingatkannya beberapa kali akan hal tersebut. Namun ketika ditanya hendak kemana adik selalu mengatakan kerja kelompok di rumah teman.

Setiap ibu marah, adik hampir tidak pernah melawan, ia biasanya hanya diam lalu masuk kamar. Ibu merasa sudah berusaha mengajak adik untuk berbicara dari hati ke hati, namun adik selalu mengatakan tidak apa-apa jika ditanya tentang masalahnya. Ibu merasa bingung harus seperti apa dalam mendidik adik dan frustasi akan tingkah adik yang semakin sulit di atur. Ibu berharap agar adik dapat memperbaiki perilaku berbohongnya dan berpamitan ketika keluar rumah. Seperti yang dikatakan Wetchler (1995) keluarga harus dapat lebih fleksibel dalam pola interaksi dan merespons yang tujuannya adalah untuk membuat hubungan lebih nyaman, aturan yang jelas dan tidak terjadi disfungsi.

Kakak ketiga mengatakan bahwa adik adalah anak yang cerdas dan sering membantunya mengerjakan tugas. Kakak sedikit menyesal karena ia kurang memberi waktu yang berkualitas untuk adik karena disibukkan urusan kuliah semester akhir. Biasanya ia dan adik berdiskusi tentang agama, teknologi dan musik. Kakak kadang bersikap keras karena ingin mendisiplinkan adik agar dapat bertanggung jawab atas hidupnya. Ia mengatakan bahwa sebenarnya sangat peduli dan ingin yang terbaik untuk masa depan adik. Namun ia sedikit menyadari bahwa kesalahannya adalah cara penyampaiannya kepada adik. Ia mengatakan bahwa kasihan melihat ibu yang sudah semakin tua dan tidak ada sosok ayah, sehingga ia merasa harus bisa menjaga keluarganya. Kakak berharap agar adik dapat menjadi lebih dekat dengannya dan lebih terbuka satu sama lain sehingga tidak terjadi salah paham yang berkepanjangan dalam keluarga.

Keterpaduan dan kemampuan beradaptasi adalah karakteristik utama dari kelompok keluarga, di mana keseimbangan antara keterhubungan emosional dan otonomi yang sedang berkembang terlihat menyatu padu dan harmonis dan menciptakan hubungan yang baik dan tidak disfungsi (Simon, 1995).

\section{Diagnosis dan Prognosis}

Berdasarkan hasil asesmen yang dilakukan berdasarkan Diagnostic and Statistical Manual of Mental Disorders (DSM-5) V61.20 (Z62.820) parent-child relational problem dengan permasalahan konflik antar anggota keluarga (ibu, kakak dan adik), kualitas hubungan anak dengan orang tua, kontrol orang tua, kekacauan pola komunikasi, disfungsi perilaku dan kognitif.

Berdasarkan sikap pada saat intervensi yang kooperatif dan serius; fungsi yang masih dimiliki yaitu kognitif, motivasi yang kuat untuk menyelesaikan masalah termasuk dalam prognosis baik. Berdasarkan sikap atau ciri masalah dengan permasalahan struktur keluarga termasuk dalam prognosis buruk. Oleh karena itu prognosis subjek adalah dubia ad bonam atau cenderung baik.

\section{Intervensi}

Intervensi dalam penelitian ini menggunakan structural family therapy dengan tujuan untuk memperbaiki sistem dalam keluarga. Model pendekatan struktural terfokus perubahan pada konteks hubungan dalam rangka rekonstruksi organisasi keluarga dan merubah pola disfungsi. Kerangka umum pendekatan struktural adalah masa kini dan masa lalu yaitu struktur keluarga dipandang dari pola transaksional permulaan, dengan kata lain struktur keluarga masa kini dipengaruhi oleh pola-pola transaksional sebelumnya. Fungsi dari terapis adalah direktur panggung, 
yaitu memanipulasi struktur keluarga dalam rangka mengubah setting disfungsional (Szapocznik et al., 1989). Sesi dalam terapi ini terdiri dari 5 sesi:

Sesi l: Asesmen awal (wawancara). Pada sesi ini masing-masing anggota keluarga diberi kesempatan untuk mengutarakan masalah yang dirasakan dan harapan hasil akhir yang diinginkan, di mulai dengan subjek, ibu dan kakak. Berjumlah 3 kali pertemuan.

Sesi II: Identifikasi masalah. Sesi ini dilakukan untuk membicarakan akar dari permasalahan keluarga seperti pola komunikasi yang keliru, aturan-aturan yang kurang konsisten, peran masing-masing anggota keluarga, konflik individu, hubungan dengan anggota keluarga, harapanharapan.

Sesi III: Restrukturisasi pola komunikasi. Pada sesi ini anggota keluarga dipertemukan untuk satu sama lain memberitahu cara atau gaya bicara yang tidak diharapkan agar dapat saling mengerti. Terapis memberi kesempatan untuk role play cara berkomunikasi seharihari yang dianggap maladaptif. Anggota keluarga di minta menjelaskan hasil dari pertemuan sebelumnya untuk semakin disempurnakan.

Sesi IV: Restrukturisasi aturan-aturan/sistem dalam keluarga. Pada sesi ini keluarga diminta untuk memaparkan aturan yang menimbulkan konflik, menyepakati pembaruan aturan bersama dan menguji cobakannya. Di pertemuan selanjutnya di sesi ini akan di bahas bagaimana pelaksanaan pembaruan aturan-aturan yang baru beserta hasilnya.

Sesi V: Evaluasi dan terminasi. Keluarga dan terapis mengevaluasi hasil terapi bersama, apakah ada hambatan dan memperbaikinya. Bagaimana pelaksanaannya, kemajuan dan harapan apa yang telah tercapai dan menutup rangkaian terapi.

\section{Hasil dan Pembahasan}

\section{Hasil}

Sebelum dilakukan intervensi subjek mengalami konflik berupa kesalahpahaman yang sering terjadi antar anggota keluarga. Adik merasa didiskriminasi dan tidak dihargai sebagai bagian dari anggota keluarga, merasa kakak terlalu berlebihan dalam menjalankan perannya sebagai kakak dan tidak adil, menganggap ibu terlalu sibuk menonton TV ketika berada di rumah, tidak mengerti keadaannya dan terlalu sering marah. Adik berasumsi bahwa kakak dan ibu merupakan satu tim dengan anggota keluarga lain dan ia berada di luar tim tersebut sehingga ia merasa sering tidak dilibatkan dalam urusan keluarga. Adik memilih untuk berbohong daripada jujur karena ia menganggap konsekuensi yang didapat akan sama saja. Adik mengatakan bahwa ia sering membolos dan pergi ke warung internet untuk melarikan diri dari keadaan rumah yang tidak menyenangkan untuknya.
Setelah intervensi, adik memahami bahwa ibu telah melakukan berbagai cara untuk mencoba memahami tetapi selama ini ia kurang menangkap hal tersebut. Adik menyadari bahwa selama ini ia telah salah paham dalam menangkap maksud ibu. Adik menjadi lebih terbuka kepada ibu dan selalu pamit ketika keluar rumah, tidak membolos sekolah dan berani bercerita tentang masalahmasalah yang dihadapinya. Adik juga menyadari bahwa kakak hanya mencoba untuk melindungi dan membantu ibu dalam mengurusnya sehingga terkadang kakak kesal dengannya. Adik merasa lebih nyaman ketika berada di rumah.

Ibu merasa tidak dihargai dan kesal kepada adik karena sering berbohong, membolos dan tidak pernah pamit jika keluar rumah. Ibu merasa jika ia telah memberikan perhatian yang cukup, mencoba memahami Adik sebisanya dan mencoba untuk menuruti kemauan Adik tetapi Adik tidak pernah beritikad baik dengan maksud baik ibu. Ibu merasa sudah mencoba berbagai cara agar Adik tidak berbohong dan membolos sekolah, tetapi tidak ada hasil signifikan yang terjadi. Ibu membiarkan kakak bersikap berlebihan kepada adik seperti memukul dalam menentukan suatu pilihan untuk adik. Hal ini dilakukan karena kakak merasa lelah dengan sikap adik yang sulit diatur. Ibu lebih percaya dan mengandalkan kakak dibandingkan adik.

Setelah intervensi ibu menyadari bahwa cara komunikasinya salah sehingga membuat adik salah paham. Ibu dapat memperbaiki cara komunikasi dalam melarang, menegur dan memerintah adik agar tidak terkesan marah atau menghakimi. Ibu merasa lebih nyaman dalam berkomunikasi dengan adik karena lebih kooperatif ketika ditanya tentang sesuatu. Ibu merasa lebih dihargai dan dihormati karena adik selalu pamit ketika keluar rumah, tidak lagi berbohong, menuruti saran dan larangan ibu. Ibu merasa senang karena adik bersedia menceritakan masalah yang sedang dihadapi serta mengenalkan kekasihnya. Ibu dapat bersikap lebih adil kepada adik-kakak jika terjadi konflik sehingga peran ibu lebih terlihat.

Kakak sering bertindak semena-mena kepada adik dalam kesepakatan perjanjian atau dalam mengatur adik. Kakak merasa kesal dengan adik karena dianggap sering merepotkan ibu, sering berbohong dan membolos. Kakak merasa kedudukannya setara dengan ibu sedangkan adik lebih rendah. Sehingga kakak merasa wajar jika marah kepada adik tanpa memberikan kesempatan untuk berbicara atau memutuskan sesuatu.

Setelah intervensi kakak mengetahui batasan perannya dalam keluarga dan dapat bersikap lebih adil kepada adik. Menentukan kesepakatan dalam pemakaian barang bersama seperti motor, laptop atau kamera. Kakak dapat mematuhi peraturan yang di buat bersama, menciptakan komunikasi dua arah. Hal ini dilakukan untuk meningkatkan perasaan saling dihargai dan dilibatkan dalam keluarga.

Secara keseluruhan, setelah dilakukan intervensi terjadi perubahan yang baik dalam cara komunikasi dan 
peran masing-masing anggota keluarga. Konflik dan kesalahpahaman berkurang, hal ini dapat dilihat dari setiap anggota keluarga mampu saling mengerti dan menghargai satu sama lain. peraturan yang buram dapat diperjelas dan disepakati secara demokratis dan adil. Ibu dapat memposisikan perannya sebagai orang tua, adik menjadi lebih terbuka, merasai lebih dihargai dan dilibatkan, kakak mengetahui batasannya, bersikap lebih adil dan netral kepada adik.

\section{Pembahasan}

Structural family therapy yang dapat memperbaiki sistem keluarga terutama pola komunikasi dan peran anggota keluarga. Terapi ini membantu subjek dalam memperbaiki disfungsi yang terjadi dalam struktur keluarga. Keluarga menjadi lebih terbuka, hangat, jujur, menjaga perasaan masing-masing, berkomuniksi dengan lebih baik, memperjelas peran dan batasan anggota keluarga. Peraturan-peraturan tertutup dan terbuka dan hierarkinya harus dimengerti dan dirubah untuk membantu penyesuaian keluarga pada situasi yang baru.

Peraturan yang belum jelas sebelumnya seperti pemakaian sepeda motor dan laptop antara adik-kakak dapat disepakati bersama dan demokratis sehingga tidak lagi menimbulkan konflik. Batasan jam malam juga telah ditentukan oleh ibu untuk kakak dan adik yang mana sebelumnya hal ini tidak jelas. Ibu menjadi lebih adil dalam menerapkan peraturan kepada adik-kakak sehingga tidak terdiskriminasi dan tidak dihargai. Adik tidak lagi membolos sekolah karena alasan tidak ada kendaraan atau marah karena kakak memakai sepeda motor tanpa perjanjian. Hal ini tentunya membantu keluarga keluar dari konflik kesalahpahaman dan tumpang tindihnya peran anggota keluarga.

Structural family therapy dapat memperbaiki organisasi dalam keluarga melalui penyusunan kembali "restructuring” hubungan keluarga. Efektifitas pendekatan ini sangat baik dalam kondisi krisis dimana batas-batas tersebut dapat dihapuskan atau dihilangkan, membuat bentuk yang ekstrim dalam hal menangkap atau melepaskan. Pendekatan ini juga memiliki nilai efektifitas yang tinggi jika keluarga terdiri dari anak remaja dimana mereka mengalami masalah dalam tingkah laku (Wetchler, 1995).

Sikap kooperatif dan motivasi keluarga yang baik juga sangat menunjang kesuksesan dalam proses terapi. Selalu hadirnya anggota keluarga di setiap sesi membuat setiap konten sesi berjalan maksimal dan dimengerti sehingga dapat membuat perubahan. Anggota keluarga selalu serius dan terbuka selama terapi berjalan. Meskipun anggota keluarga yang tidak serumah berhalangan hadir, subjek bersedia untuk membicarakan kesepakatan-kesepakatan yang telah dirancang dalam terapi agar anggota keluarga yang berada di luar rumah tidak mengacaukannya.

Reorientasi yang baik membentuk sistem baru yang lebih baik pula. Masing-masing anggota keluarga membenahi persepsi kelirunya selama ini kepada anggota keluarga lainnya. Orientasi yang lebih baik membuat setiap anggota keluarga dapat memahami sudut pandang anggota keluarga lainnya sehingga dapat saling mengerti dan menghargai satu sama lain.

Masing-masing keluarga memiliki respon yang tinggi untuk menyusun kembali teknik-teknik restrukturing dengan garis besar kekuatan antara anggota dan perbedaan sub-sistem. Pembentukan garis-garis besar fungsi yang lebih baik secara umum merupakan hasil dalam perkembangan kooperatif dan efektifitas pemecahan masalah yang didasari pada kemunculan angota keluarga yang komponennya berbeda dalam sistem keluarga (Aponte, 1992).

\section{Simpulan}

Structural family therapy yang dilakukan sebanayak 5 sesi efektif untuk memperbaiki sistem keluarga. Dapat diaplikasikan pada keluarga yang memiliki permasalahan dalam sistem seperti komunikasi dan peran masing-masing anggota keluarga. Terapi ini dapat menurunkan konflik seperti kesalahpahaman, memperjelas aturan-aturan yang berlaku dalam keluarga dan memenuhi peran masingmasing sesuai kapasitas

\section{Referensi}

Aponte, H. J. (1992). Training the person of the therapist in structural family therapy. Journal of Marital and Family Therapy, 18, 269-281. https://doi.org/10.1111/j.1752-0606. 1992.tb00940.x

Connell, C. (2010). Multicultural perspectives and considerations within structural family therapy: the premises of structure, subsystems and boundaries. Insight: Rivier Academic Journal, 6(2), 1-6.

Cook, R. (2007). The golden thread that unifies effective treatments Review of the book Second order change in psychotherapy, by J. S. Fraser \& A. D. Solvey. American Psychological Association, 12, 15.

Cooper, L. G., Gooding, J. S., Gallagher, J., Sternesky, L., Ledsky, R., \& Berns, S. D. (2007). Impact of a family-centered care initiative on NICU care, staff and families. Journal of Perinatology: Official Journal of the California Perinatal Association, 27(Suppl 2), S32-S37. https://doi.org/10.1038/ sj.jp. 7211840

Friedman, M. M. (2010). Buku ajar keperawatan keluarga, Ed 5 tahun 2010. EGC.

Minuchin, S. (1974). Families and family therapy. Harvard University Press.

Minuchin, S. (1982). Reflections on boundaries. American Journal of Orthopsychiatry, 52(4), 655-663. https://doi.org/ 10.1111/j.1939-0025.1982.tb01455.x

Simon, G. M. (1995). A revisionist rendering of structural family therapy. Journal of Marital and Family Therapy, 21(1), 17-26. https://doi.org/10.1111/j.1752-0606.1995.tb00135.x

Szapocznik, J., Rio, A., Murray, E., Cohen, R., Scopetta, M., Rivas-Vazquez, A., Hervis, O., Posada, V., \& Kurtines, W. (1989). Structural family versus psychodynamic child therapy for problematic Hispanic boys. Journal of Consulting 
and Clinical Psychology, 57(5), 571-578. https://doi.org/10. 1037/0022-006X.57.5.571

Vetere, A. (2001). Structural Family Therapy. Child Psychology and Psychiatry Review, 6(3), 133-139. https://doi.org/10. 1111/1475-3588.00336
Wetchler, J. L. (1995). A conservative response to Simon's revision of structural family therapy. Journal of Marital and Family Therapy, 21(1), 27-31. https://doi.org/10.1111/ j.1752-0606.1995.tb00136.x 